\title{
J"It's in Our DNA": Climate Change and Perceived Resilience and Adaptive Capacity in Nature-Based Tourism in Lofoten, Norway
}

\author{
Karin MARie Antonsen, ${ }^{\mathrm{a}}$ Brigt Dale, ${ }^{\mathrm{a}}$ and Stephanie MAYeR ${ }^{\mathrm{b}}$ \\ a Nordland Research Institute, Bod $\varnothing$, Norway \\ ${ }^{\mathrm{b}}$ Norwegian Research Centre, Bergen, Norway
}

(Manuscript received 5 February 2021, in final form 14 October 2021)

\begin{abstract}
In 2018, tourism was the fastest growing sector in the world, accounting for $10 \%$ of all jobs worldwide and $10.4 \%$ of the world's gross domestic product. Tourism is often cited as a strategy for future development at national, regional, and local levels. This paper takes a closer look at the Lofoten Islands in northern Norway, where the increase in nature-based tourism over the last two decades has occurred in parallel with the restructuring of the traditional fisheries. Nature-based tourism in rural regions relies heavily on a broad range of ecosystem services (ES). This paper will present how stakeholders in nature-based tourism assess the influence of climate change on ES crucial for their activities and for the destination and will outline and explain how the practitioners perceive their ability to withstand or adapt to these changes. With the aid of models depicting potential future climate scenarios, we initiated discussions with stakeholders and found that tourism actors have only to a minor degree sought to develop strategies to increase adaptive capacity and therefore resilience to climate change. Based on our findings, we discuss how the adaptive capacity of individual actors in nature-based tourism forms the basis for the system's resilience, and that a general resilience focus also forms the basis for transformational capacity, a capacity needed for future resilience. In light of our findings and analyses, we will conclude by reflecting on overarching systemic transformative tendencies in the wake of coronavirus disease 2019 (COVID-19) and obligations contained in the Paris Agreement on reducing global emissions.
\end{abstract}

KEYWORDS: Adaptation; Arctic; Climate change; Coastlines; Resilience; Social Science; Vulnerability

\section{Introduction}

Tourism is highlighted as an important strategic sector for postindustrial economic development (World Travel and Tourism Council 2019b). Up to the coronavirus disease 2019 (COVID-19) outbreak, tourism was the fastest growing industry in the world. In 2018, international travel reached 1.4 billion international arrivals, and the industry accounted for $10 \%$ of all jobs and $10.4 \%$ of the world's gross domestic product (GDP; World Travel and Tourism Council 2019a,b, p. 2). It was expected that the growth in international travel would continue; however, COVID-19 has made these expectations uncertain, and climate change-related challenges are further exacerbating the situation for an industry dependent on movement and excessive energy use.

The main rationale for this study, however, is related to another set of climate-change risks, and how they may impact nature-based tourism, and in particular adventure-based tourism (AT), in the future. The term nature-based tourism refers to "all forms of tourism-mass tourism, adventure tourism, low-impact tourism, ecotourism-use natural resources in a wild or undeveloped form" (Goodwin 1996, p. 287). According to the World Tourism Organization (UNWTO) and the Adventure Travel Trade Association (ATTA), AT refers to

¿ Denotes content that is immediately available upon publication as open access.

Corresponding author: Karin Marie Antonsen, kan@nforsk.no tourism where at least two of the following elements are included: physical activity, natural environment, and/or cultural immersion (World Tourism Organization 2014, p. 10). $\mathrm{AT}$ is one of the fastest growing subcategories of tourism (World Tourism Organization 2014), and all three elements of AT included in UNWTO's definition will be addressed in this paper.

As early as the 1980 s, scholars focusing on nature-based tourism became aware of the socioeconomic and environmental impacts of climate change, with ski resorts and beach fronts being studied with the aim of understanding their vulnerability to climatic changes (Scott et al. 2012; Newsome et al. 2013). Coastal and marine environments are important for tourism (Hall 2001), and their particular vulnerability to climate change in case of extreme climate events and sea level rise has been raised (see Hall 2001; Moreno and Becken 2009). Climate change impacts on ski tourism are the impacts most covered by research, initially through climate change impact assessments and sensitivity assessment studies, followed by stakeholder perception studies, climate sensitivity analyses, integrated assessments, and skier behavioral response studies (Dannevig and Aall 2015; Gildestad et al. 2017; Steiger et al. 2017). Despite these efforts, according to Scott and others (Scott et al. 2012; Cole et al. 2016), tourism stakeholders' perceptions and responses to environmental and climate change are still poorly understood. What has become apparent, though, is that "a lack of understanding of the integrated impacts of climate change and the effectiveness of adaption strategies potentially hinders the development of resilient tourism operations and destinations" (Scott et al. 2016, p. 1). Addressing risk perceptions of ski industry 
stakeholders, Hopkins (2013) found a clear distinction in risk perceptions where current weather variability was perceived as a current risk, while future climate change was regarded as a more distant threat, a point we will return to in the analysis. Other scholars have stressed that personal experiences of weather preceding the study seem to play an important role in shaping perceptions of climate change (Wyss et al. 2014a).

According to Scott et al. (2012) there has been a tendency to examine potential climate change impacts in terms of one element rather than considering the broader system. In this vein, Scott et al. (2016) analyze the implications for the industry of the assessments of the IPCC's Fifth Assessment Report on climate change. ${ }^{1}$ Using the Lofoten Islands as an example, this paper seeks to contribute to the understandings of the combined effects of climate change impacts, adaptive capacities of actors, and the resilience and transformability of the nature-based tourism sector and ultimately the socioecological system it is a part of. Specifically, we will present the relation between stakeholders' perceptions of future climateinduced changes to ecosystem services (ES) that they themselves identify as crucial, and assessments of the adaptive capacity, resilience, and transformability of the nature-based tourism system.

We will seek to answer the following research questions:

1) Which potential climate change-induced impacts on ecosystem services are identified by stakeholders in naturebased tourism?

2) How do stakeholders in nature-based tourism perceive their own specific vulnerability and adaptive capacity-and the overall resilience of the industry-to climate-induced changes?

Based on the findings of these inquires we will discuss in what way diversity and flexibility contribute to adaptive capacity, resilience, and transformability in the nature-based tourism industry.

\section{Theoretical framework}

\section{a. Resilience, adaptive capacity, and transformability}

We find the applicability and analytical potential of the resilience concept fruitful for this case, as resilience is closely related not only to adaptive capacity and adaptability (Miller et al. 2010; Biggs et al. 2012), but also to transformability (Folke et al. 2010). With its origin in natural science and ecology, the resilience concept originally focused on "the capacity of ecosystems with alternative attractors to persist in the original state subject to perturbations (Folke et al. 2010, p. 1). Adaptability is generally referred to as "the capacity of actors in a system to influence resilience" (Walker et al. 2004, p. 1), thus referring back to the systemic understanding of resilience. A way of defining the adaptive capacity to climate change challenges of social actors would be "the ability of a

\footnotetext{
${ }^{1}$ See https://www.ipcc.ch/report/ar5/syr/, accessed 4 October 2021.
}

sector, community, or household, to cope with, adjust, or recover from an exposure to, for example, extreme weather" (Hovelsrud et al. 2018, p. 4), thus reducing vulnerability (Nelson et al. 2007). Adaptive capacity depends on underlying factors such as economic, natural, and environmental resources and institutions, but also on social and human capital, awareness, information management, participation levels and risk-spreading processes; all factors pointing to embedded agency and proactiveness.

In the study presented here, we are dealing with what is called a complex social-ecological system (SES), ${ }^{2}$ where nature-based tourism activities are both dependent on and influence natural surroundings in a multisectoral environment. These systems will to a varying degree be resilient to new challenges based on actors' adaptive capacities, but also to their transformability, that is, their capacity to "create a fundamentally new system when ecological, economic, or social structures make the existing system untenable" (Folke et al. 2010, p. 3). The resilience concept thus has the potential to describe a system's ability to incorporate change, and to withstand, recover or sometimes even rebound in a strengthened way from shocks, stress, or disturbances (Folke 2006; Smith et al. 2009; Wyss et al. 2014b; Linnenluecke 2015), but also, to unveil preconditions for transformability (Folke et al. 2010).

Flexibility and diversity are crucial capacities of a resilient system (Manring 2014; Wyss et al. 2014b; Béné and Doyen 2018). But to focus on specific shocks to parts of the systemwhat Folke et al. (2010) called specified resilience-may in fact increase the risk of future instability. Therefore, it is argued, a general resilience focus opens for a broader understanding of a system's capability to adapt, and ultimately its transformative capacities (Folke et al. 2010). Indeed, transformability has much in common with general resilience, they argue, as both concepts refer to the actions of participants evaluating the current situation, combining knowledge and experiences, potentially invoking "shifts in perception and meaning" (Folke et al. 2010) and thus transformational change, as in "a change in the nature of the stability landscape, introducing new defining state variables and losing others" (Folke et al. 2010, p. 5). Further, Carr (2019) argues that for resilience to foster the change needed to face the rapidly changing preconditions for SES, the focus must shift. In short, instead of focusing on systemic parts interacting to maintain its structure and function, an understanding of resilience as a project in which "social and natural processes . . . create and maintain particular socio-ecological states that further specific goals of those living in that system" (Carr 2019, p. 71) is vital. With this broader conceptualization, the way the adaptive capacity of actors influences resilience is not only as a conservative force maintaining the status quo, but as active participants in constantly redefining and renegotiating the very basis for the stability of the system, right up to the point of enabling transformability, as a means to foster future resilience.

\footnotetext{
${ }^{2}$ See description in Folke et al. (2010).
} 
The resilience perspective is gaining attention in tourism research for precisely highlighting the ability of the sector to cope with challenges and changes within the established system (Becken 2013). We concur and find the concept useful for understanding how the tourism industry and its enterprises could respond and adapt to increasing global change and disturbances (Biggs et al. 2012), and how broader systemic changes might trigger changes that, at different levels, might become transformative, in line with Folke et al.'s (2010) conceptualization of resilience.

Walker et al.'s (2004) description of a resilient system similarly mirrors this inclusive ambition with regard to the resilience concept. In their framework, a system is still resilient if it remains within what is its border of thresholds. A system's resilience thereby refers to the width or limit of a stable domain, which they refer to as its latitude, that is, the borders from within which the system can recover and return to stability (Walker et al. 2004). This means that if a tourism system can handle several changes without losing its ability to recover, it has a large latitude, that is, a wide range of adaption strategies available before crossing a threshold that makes recovery difficult or impossible.

Finally, effects of cross-scale interactions at lower and higher scales will also affect resilience and adaptive capacity. Gunderson and Holling (2002, cited in Manring 2014) argue that SES need to be examined from social, economic, and ecological views (see Folke et al. 2010). Climate change-induced drivers for change do appear, and have different consequences, at different scales (Luthe and Wyss 2014). Contextual manners such as market fluctuations, geopolitical tensions, environmental politics, technological development, demographic changes, customer behavior (including increased environmental concerns), and-as we all now know-pandemics, should all be considered when assessing resilience and adaptation strategies of SES. In other words, tourism actors depend on conditions influenced by climatic, ecological, institutional and market variations, often beyond their control. Thus, multiple variables combined make up the SES within which the tourism industry develops (Folke et al. 2010). Adaptational strategies must therefore be understood as efforts to meet multiple threats and challenges to the present state. And as has been mentioned, this multiplicity of challenges makes the identification of specific resilience to climate change difficult indeed.

\section{b. Ecosystem services}

Nature-based tourism depends on a great number of specific ES (Hall 2010). The concept ES was put on the agenda by the United Nations Millennium Ecosystem Assessment (MA) and highlights nature's contribution to human wellbeing through delivering "provisional services such as food, water, timber, and fibre; regulating services that affect climate, floods, disease, wastes, and water quality; cultural services that provide recreational, aesthetic, and spiritual benefits; and supporting services such as soil formation, photosynthesis, and nutrient cycling" (Reid et al. 2005, p. V). Naturebased tourism itself is, as defined here, considered a cultural
ES providing recreational and aesthetic benefits and values (de Groot et al. 2010; Chan et al. 2012). ${ }^{3}$

Duffy (2015) argues that changes in and degradation of ES will affect tourism in ways not yet understood. Additionally, there are multiple ways in which tourism itself can propel changes in ES in ways that might undermine the sector's own existence (Church et al. 2017), for example, through overexploitation and overtourism leading to degradation of ES (Newsome et al. 2013). That said, the paradox of being an industry basing its economic growth on a dependence on specific ES that are threatened by the consequences of its growth, makes nature-based tourism a potentially vulnerable system (Goodwin 1996; Fennell 2015). Conversely, though, tourism can also contribute to the maintenance of ES that serve the industry's interest, for example, by building and maintaining hiking trails and increasing the knowledge and awareness of ecosystems through such efforts as guided tours and farm tourism. Thus, the nature-based tourism sector's utilization of ES can enable access to services that may also benefit local communities (Church et al. 2017). In our study the identification of critical ES for nature-based tourism is part of the methodological framework in assessing the sector's vulnerability, adaptability, resilience, and transformative capacity to climate changes. Milcu et al. (2013) argue for a holistic understanding of the human-environment relationship of cultural ES. This aligns with our theoretical framework highlighting the cross-scale integration of actions when seeking to understand adaptation, resilience, and transformability in SES.

\section{Methods}

Our methodological framework is inspired by the assessment of the tourism system's vulnerability to climate change presented by Moreno and Becken (2009) and the assessment of specific and general resilience to climate change given by Becken (2013). The assessments presented in this article are based on coproduction of knowledge between representatives of different scientific disciplines, and 16 stakeholders engaged with nature-based tourism (see Table 1).

Producing knowledge beyond scientific and professional boundaries requires translation of abstract theories and models in communication with practitioners (Cash et al. 2002; Norström and Cvitanovic 2020). Initially we interviewed three key informants separately, including the manager of the regional destination management organization (DMO), and managers of two companies. The key informants were strategically chosen because of their long-time engagement with nature-based tourism from different stakeholder perspectives. Central questions addressed in the interviews were which ES the stakeholders perceived as important for their business and for nature-based tourism in the region, which climate-induced changes they considered as most threatening to these ES and to their activities now and in the future, and how the stakeholders perceived their own vulnerability and adaptive

\footnotetext{
${ }^{3}$ See also https://www.millenniumassessment.org/documents/ document.356.aspx.pdf, accessed 18 June 2021.
} 
TABLE 1. Information about informants/stakeholder and generation of data.

\begin{tabular}{|c|c|c|c|}
\hline Informant/stakeholder & Code & Activities & When \\
\hline Key informant-DMO & s-1 & $\begin{array}{l}\text { Initial workshop in project } \\
\text { group, interview, and field } \\
\text { conversations }\end{array}$ & Spring 2018-spring 2019 \\
\hline $\begin{array}{l}\text { Key informant }- \text { manager in } \\
\text { business offering nature- } \\
\text { based activities }\end{array}$ & $\mathrm{s}-2$ & $\begin{array}{l}\text { Interview; several field } \\
\text { conversations }\end{array}$ & $\begin{array}{l}\text { Spring and fall 2018; summer } \\
\text { and fall 2019; fall } \\
\text { 2019-spring } 2020\end{array}$ \\
\hline $\begin{array}{l}\text { Key informant-manager in } \\
\text { nature-based activities }\end{array}$ & s-3 & Interview & Spring 2018 \\
\hline $\begin{array}{l}\text { Manager in accommodation } \\
\text { and nature-based activities }\end{array}$ & s-4 & Workshop & Fall 2018 \\
\hline $\begin{array}{l}\text { Manager in accommodation } \\
\text { (rorbu) and nature-based } \\
\text { activities }\end{array}$ & s-5 & Workshop & Fall 2018 \\
\hline $\begin{array}{l}\text { Manager in accommodation } \\
\quad(\text { rorbu })\end{array}$ & s-6 & Workshop & Fall 2018 \\
\hline $\begin{array}{l}\text { Manager in nature-based (sea) } \\
\text { activities }\end{array}$ & s-7 & Workshop + conversation & Fall 2018 \\
\hline Organization; landowners & $\mathrm{s}-8$ & Workshop + conversation & Fall 2018 \\
\hline $\begin{array}{l}\text { Employee in nature-based } \\
\text { (sea) activities }\end{array}$ & s-9 & Workshop & Fall 2018 \\
\hline Organization landowners & s-10 & Workshop & Fall 2018 \\
\hline Manager and nature guide & s-11 & $\begin{array}{l}\text { Workshop }+ \text { field } \\
\text { conversations }\end{array}$ & Fall 2018 \\
\hline $\begin{array}{l}\text { Manager in accommodation } \\
\text { and cultural heritage }\end{array}$ & $\mathrm{s}-12$ & Workshop & Fall 2018 \\
\hline Public sector & s-13 & Workshop & Fall 2018 \\
\hline Nature guide; employee & s-14 & $\begin{array}{l}\text { Interview }+ \text { field } \\
\text { conversations }\end{array}$ & Spring 2019; fall 2019 \\
\hline $\begin{array}{l}\text { Manager in accommodation } \\
\text { (fishing camp) and fishing } \\
\text { tourism }\end{array}$ & s-15 & $\begin{array}{l}\text { Interview }+ \text { field } \\
\text { conversations }\end{array}$ & Fall 2019 \\
\hline $\begin{array}{l}\text { Manager in accommodation } \\
\text { and cultural heritage } \\
\text { (fishing village) }\end{array}$ & s-16 & Field conversation & Fall 2019 \\
\hline
\end{tabular}

capacity and the industry's resilience to present and future weather and climate change. The interviews were not recorded, and the analysis is based on the researchers' notes.

In October 2018, 10 tourism stakeholders met for an open workshop invitation sent to all members of the DMO and posted on social media. Initially the researchers provided a short introduction to ES. ${ }^{4}$ The participants were divided into groups and challenged to identify ES crucial for their and others' business or interests. Every group wrote notes into a form in alignment with Table 3 (described in more detail below) and presented in plenary. The researchers then presented preliminary data identified in the initial interviews, followed by a plenary discussion. Based on a presentation of existing high emission future climate projections scaled to the County of Nordland held by the researchers, the procedure from session one was repeated, and the participants were challenged to propose climate change indicators potentially affecting the specific ES of relevance for their activities (and the destination). Models for temperature, precipitation and

\footnotetext{
${ }^{4}$ We used the Norwegian term naturgoder.
}

snow cover were based on $12 \times 12 \mathrm{~km}$ data from the European domain of the Coordinated Regional Downscaling Experiment (EURO-CORDEX) collaboration. ${ }^{5}$ Models for sea level rise were based on a web tool for mapping storm surge and sea level rise available at the Norwegian Mapping Authority. ${ }^{6}$ The session also included discussions about experienced changes in weather conditions. In a last session we treated climate change adaption and adaptive capacity following the same procedure. The participants were in plenary challenged to assess their own and the industry's adaptivity and adaptive capacity (qualitatively, not by using a scale) and to suggest how it could be increased. Three researchers, one of whom had the sole task of writing notes, took part in the sessions. All three researchers took notes, and a report was merged from these and from the forms collected from the participants.

Over a period of one year following the workshop, we conducted several follow-up conversations with four of the

\footnotetext{
${ }^{5}$ Available at https://klimaservicesenter.no/climateprojections.

${ }^{6}$ Based on a report available at https://www.miljodirektoratet. no/globalassets/publikasjoner/m405/m405.pdf.
} 
participants from the workshop, and four key informants, including a nature guide and an operator of accommodation and fishing tourism. The new key informants were chosen because they utilize ES considered particularly vulnerable to climate change. Based on the data generated and discussions in the research group, downscaled regional climate projections for Lofoten were tailored by the authors. ${ }^{7}$ These projections were sensitive to the specific perceived impacts, threats, and knowledge needs assessed by the stakeholders. The tailored projections were finally presented to and discussed with four stakeholders in separate interviews where notes were taken by the researchers. The focus for these interviews was vulnerability and adaptive capacity and the data from these interviews are incorporated in the analysis. The data were generated before the onslaught of COVID-19 and must thus be seen in retrospect as representing a status quo for a booming tourism sector that has since faced severe challenges.

\section{Case description: Lofoten}

Situated just above the Arctic Circle in northern Norway, the Lofoten Islands is known for its pristine nature, fishery heritage, and-more recently - the struggle to keep the region free from petroleum extraction (Dale and Kristoffersen 2018; Dale et al. 2018). Despite its harsh environment, the region has been populated for millennia (Bertelsen and Urbańczyk 1988) and people in Lofoten have always been intrinsically tied to the sea as a main source of food and income. Over time, the main source of the region's riches has been access to the Arcto-Norwegian cod (Gadus morhua, called skrei). Every winter, the skrei migrates from the Barents Sea to the waters of Lofoten to spawn. This is the basis for the great fisheries-Lofotfiske. Up to the twentieth century, these fisheries attracted up to 30000 fishermen per season, and have together with the export of skrei and stockfish been of major importance for both the national economy and the survival of communities all along the Norwegian coast (Jentoft and Kristoffersen 1989; Sundby and Nakken 2008; Bjørkan and Veland 2019).

Thus, the connection to the sea, and to the skrei itself, is an important identity marker for people in Lofoten (Antonsen 2011; Dale 2011, 2016). The traditional drying racks covered with fish, its picturesque fishing villages, fishing boats, docks and harbors are crucial elements of the cultural landscape. However, the restructuring of fisheries during the post-World War II period led to decreasing demand for a fisheries workforce (Johnsen and Vik 2013). The development of a thriving tourism industry (see below) has led to a decline in dependency on the fisheries, but also the worst demographic consequences being averted. The population figures have been relatively stable (approximately 24500 inhabitants) in this period, unlike most parts of rural northern Norway, which are experiencing population decline.

\footnotetext{
${ }^{7}$ A methodological paper on the development of these projections is forthcoming (S. Mayer et al. 2021, unpublished manuscript).
}

Because of the Gulf Stream, average winter temperatures are just below $0^{\circ} \mathrm{C}$ and average summer temperatures are $12^{\circ} \mathrm{C}$. Average precipitation is approximately $1900 \mathrm{~mm}$. Storms, which can occur more than five times annually, affect infrastructure and transport systems. It is not uncommon for bridges and roads to be closed and for boats to be forced to cancel calls to port because of bad weather. Climate unpredictability in different seasons over time makes short-term changes (as in more subtle changes in heat, precipitation, and extreme weather) hard to detect. Therefore, at the time of writing, there is no consensus around current impacts of human-induced climate changes in Lofoten. It is projected, though, that there will be detectable changes in a future beyond $1.5^{\circ} \mathrm{C}$ (see, e.g., IPCC 2018). The projections of future climate used in discussions with stakeholders are presented in the methods section. Tailored projections for Lofoten based on the analysis of qualitative data are presented in the findings section.

\section{The tourism sector in Lofoten}

The coexistence with the traditional fisheries should not be underestimated in understanding the recent developments of the tourism sector in Lofoten. The sociocultural heritage, both the physical remnants of the fisheries and the self-proclaimed ability to master the sea and to be resilient is the de facto basis for the development of a major tourism industry in the region (Karlsson and Dale 2019).

The marketing of the Lofoten Islands as a tourism destination is dominated by nature, which is also the main motivation for tourists to visit the region (Prebensen et al. 2013; Innovasjon Norge 2018; Kaltenborn et al. 2019; Antonsen and Enger 2020). A great variety of nature-based experiences are offered by local operators, and many operators classify themselves into the broader adventure tourism segment (see Weber 2001 paraphrasing Hall and Weiler's definition) including both high risk-seeking and insight-seeking customers.

Annual reported guest nights in hotels and camping sites in Lofoten has more than doubled from approximately 250000 in 2000 to almost 560000 in $2019 .{ }^{8}$ In addition, it was calculated for 2019 that approximately 420000 guest nights in total were spent in, variously, Airbnb facilities (209 000), on cruises (93 000), on the coastal express (Hurtigruten) $(70000)$ and in second homes $(50000) .{ }^{9}$ A rising but unknown number of tourists are also making use of the freedom to roam and prefer free camping in tents, caravans, and recreational vehicles

\footnotetext{
${ }^{8}$ The official statistics from Statistics Norway for 2019 (SSB.no at https://www.ssb.no/en/statbank/list/overnatting) are based on the reporting from 18 hotels and 44 camping sites (high season) including smaller units with houses, apartments and rorbuer. The historical data series were downloaded early 2020. These data series for the regional level are no longer available at this or any other site from Statistics Norway.

${ }^{9}$ Data from Airbnb are available via Destination Lofoten, data from cruises are available via the Lofoten Cruise Network, data from second homes are calculated based on 2200 registered second homes in Lofoten (SSB.no at https://www.ssb.no/natur-og-miljo/ areal/statistikk/fritidsbyggomrader), and data from Hurtigruten are available at SSB.no (https://www.ssb.no/statbank/table/06207).
} 
(RVs). Peak season is in the summer months, but winter tourism has been on the rise with an increase in guest nights (January-April) from 40000 in 2010 to nearly 110000 in 2019 (Statistics Norway; SSB.no). ${ }^{10}$ Foreigners make up a total of $57 \%$ of reported guest nights (especially from Germany, Sweden, France, Italy, and Switzerland). The share of foreign visitors relative to domestic increased year by year-up to the March 2020 outbreak of COVID-19.

Visitors arrive by car, ferry/express ferry, air flight, and cruise. There are numerous options for accommodation, including the popular traditional fishing cabins (called rorbu). There is a long history of private lodging originating from the seasonal fisheries, which now has increased dramatically through Airbnb.

According to the regional DMO, visitors' behavior has changed recently from traditional sightseeing to adventure tourism. This means more independent travelers with a desire to explore, resulting in more visitors utilizing ES physically, not only as scenery. The most iconic mountain peaks and beaches have become especially exposed. In combination with the increased number of visitors, this has led to a debate regionally about the sustainability of the sector. During the last couple of years, business plans to a larger extent than before express an effort to ensure a coexistence that benefits the future sustainability of the islands.

\section{Findings}

\section{a. Potential climate change-induced impacts on ecosystem services valued in nature-based tourism in Lofoten}

For analysis, we have divided the nature-based tourism system of Lofoten into subsystems, shown in Table 2 (Becken 2013). The categories are based on the stakeholders' utilization of different ES, products available at the DMO's website and the authors' (1 and 2) contextual knowledge after living in Lofoten for 18 years.

As shown in Table 3 there is a great breadth of different ES perceived to be important, including biodiversity and key species. Across the subsystems, several stakeholders highlight clean nature and the freedom to roam, including the accessible shoreline, beaches, islets and inlets, peace and quiet, protected nature and local communities as overarching ES crucial for nature-based tourism in Lofoten. Some also refer to overtourism and accompanying contamination as major threats to ES, and thus to the attractiveness of the region for both visitors and locals. The stakeholders' assessments of critical ES for nature-based tourism illustrates an interconnectedness and mutual dependency of many cultural ES, but also provisioning and regulating ES as defined by Reid et al. (2005, p. V).

\section{b. Perceptions of adaptive capacity to weather and climate-induced changes}

We asked the operators how they cope with rapidly changing variables such as bad weather events, and how they think

\footnotetext{
${ }^{10}$ The data series was downloaded in 2020 at https://www.ssb. no/statbank/list/overnatting, but historical data series for the regional level are no longer available.
}

that they will cope with future projected climate changes (slowly changing issues). The response was often that they already do have flexibility and adaptability embedded in their planning. As s-11 says, "It's in our DNA." S-5 adds on, "We are forever the entrepreneurs. Everything changes constantly. Even from day to day."

Among operators within snow-based activities, ecotourism, and some parts of the sea-based subsystem the perception of a high adaptive capacity seems to be embedded in the business models. As s-5 explains: "If you don't have a plan B, you're dead." S-11 points out that "our adaptive capacity is high. We do fine tuning every day." Within the snow-based subsystem the adaptive capacity is all about being flexible and able to offer alternative activities due to changing snow and weather conditions; the skiing or walking on snowshoes might be relocated or replaced with a walk with crampons. Also, within the sea safari subsystem, where fishing is one of the main activities beside sightseeing, the perceived adaptive capacity seems to be high. According to s-2 they never cancel prebooked activities due to precipitation, and if it is too windy, they always have a plan B, either by relocating to where the water is calm or by switching to land-based activities.

Operators that offer accommodation in traditional fishermen cabins (rorbuer) fear rising temperatures and consequently rising sea levels the most, because many of the old cabins are located near the flood target. S-16 also stated that the needs to maintain the rorbuer, and thereby the costs, have increased due to what they have experienced as increased humidity in recent years. S5 , s-12, and s-15 explained that a lot of adjustments have already been made due to climate adaptation strategies implemented in public planning. On the basis of risk assessments in accordance with the Norwegian Planning and Building Act, new rorbuer are not permitted to be built as close to the flood target as the authentic ones, and concrete is replacing traditional wooden poles. The stakeholders are somewhat afraid that these adaptions will reduce the visual attractiveness and authenticity. This illustrates how cultural ES (Chan et al. 2012) are also valued and assessed as vulnerable to climate change for nature-based tourism, and how climate change-induced adaptations also may reduce aesthetic qualities and consequently have negative economic impacts for tourism (Houston 2002).

Loss of key species was perceived by several participants as a potential outcome of climate change. We asked s-15, a fisherman who also runs a fishing tourism resort (mainly in the summer season), if he feared that warmer sea could result in changing migration patterns of the skrei (Sundby and Nakken 2008). To our surprise, he did not see the skrei as vital for their business:

Well, we do not depend on the skrei. Maybe I will tone down the fishing part ... We are working on expanding the season and see good occupancy also in April and May. The cod is not critically important for the business. As long as they (the tourists) get some fish. Our preferred customers are not the ones that fish the most. They want cheap accommodation.

Thus, his business is now strategically changing to a new segment by rising the standard of their facilities and consequently also the price level. "We are raising the bar to a new level." Combining the tourism business with being a 
TABLE 2. Subsystems of nature-based tourism in Lofoten, based on data made available for the study showing monthly sales of nature-based activities through the portal of the DMO.

\begin{tabular}{|c|c|}
\hline Subsystem & Description \\
\hline Sea safari & Guiding from motorboats, mainly rigid inflatable boats \\
\hline Fishing tourism & $\begin{array}{l}\text { Fishing trip with skipper and guide or renting boats and equipment without a } \\
\text { guide (some offer both); some combine renting out of boats and equipment } \\
\text { with accommodation (fishing camps) }\end{array}$ \\
\hline Birdwatching and phototourism & $\begin{array}{l}\text { Also as part of sea safari, hiking, ecotourism, cultural heritage and "hunting } \\
\text { natural phenomena" }\end{array}$ \\
\hline Sea-based activities & Diving, surfing, standup paddling, and kayaking \\
\hline Hiking/alpine touring and mountain climbing & From strolls in flat terrain to exposed climbing \\
\hline Snow-based activities & Randonnée skiing (backcountry skiing in alpine terrain) and snowshoes \\
\hline "Exploring natural phenomena" & Northern lights or midnight sun safaris \\
\hline Ecotourism & $\begin{array}{l}\text { One operator is certified as an ecotourism operator, but several operators offer } \\
\text { "ecofriendly" experiences }\end{array}$ \\
\hline Cultural heritage & Museums, cultural landscape, art and galleries, and authentic fishing villages \\
\hline Golf & 18-hole golf course \\
\hline Local food and farm tourism & $\begin{array}{l}\text { Fish [including stockfish, which is Indicazione Geografica Protetta (IGP)/ } \\
\text { Protected Geographical Indication (geographically protected)], and lamb, but } \\
\text { also vegetables, herbs, berries, cattle, and goat; Lofoten has two ecofarms } \\
\text { producing and selling goat cheese and meat from their farm sale; guided } \\
\text { horseback riding }\end{array}$ \\
\hline
\end{tabular}

fisherman, the winter season of fishing tourism is not his priority.

We found a shared sense among the practitioners that the weather has been changing, especially the last 10-20 years, a sentiment that cannot scientifically be identified as climate change. Some have already adjusted and adapted to what they have experienced as more extreme/unpredictable weather by not offering guided kayaking tours in most weather exposed areas, by relocation to or expansion of potential territory (like moving skiing trips farther east in the region where the temperatures are lower), by replacing small boats with bigger ones, by not relying on renting small boats to tourists and by preparing customers for even more unpredictability in general. Some also reported that they have changed their portfolio from "extreme" to "soft" adventures or are working in new segments like health and well-being, mindfulness, coaching, and cultural heritage. One reason is that such activities do not depend on weather or climate to the same extent. "We can still use the scenery, silence and infrastructure of Lofoten as an important backdrop," s-4 says. S-11, an experienced nature guide, complemented these arguments, saying that "an incredible amount of money is spent to sell the extreme-but it is so poorly paid. Soft adventure is the segment that pays the best."

Some operators, especially within fishing and other seabased tourism, did not express the same adaptive capacity due to rapidly changing variables as others. Some cancel trips without a plan B: "We don't have a choice if there is too much wind to go out with the boat," s-7 says.

\section{c. The tourist's behavior and adaptivity}

Operators in Lofoten report several changes in tourist behavior. In addition to the turn from sightseeing to adventure tourism mentioned earlier, booking happens much later than before, especially when it comes to activities, but with accommodation too. S-11 estimates that average time of booking for inbound visitors has decreased from nine to three months in the last decade. Only large groups still book a year in advance. Individual travelers in smaller groups are most likely to book experiences the night before, or even the same morning, s-2 tells. With full access to information online, the visitors can easily assess weather forecasts and select the best products "just in time." This change means more unpredictability for the operators. Another change mentioned was the traveling patterns. While visitors, according to stakeholders, might stay for one or even two weeks 10 years ago, recent guests mostly stay for only two or three days at the same accommodation before moving on. "Nowadays tourists want to experience all of Lofoten in one week." The changes from solely a summer season activity to a year-round industry has increased visitors' expectations of professionality, but also their willingness to pay. As s-11 puts it, "If you go six years back, everybody asked about price. It was low-budget travelling. Today, customers know what they want and put five times the money into it. They pay without questions."

\section{d. Future climate projections for Lofoten for precipitations and temperatures}

As mentioned, assessing the current influence of climate change in Lofoten is a complex issue. Most of the stakeholders are, however, concerned that climate change-induced increased temperatures could cause more bad weather in the future and that extreme weather will impact infrastructure. The combination of increased precipitation, higher temperatures, and shorter periods of snow cover could also lead to the degradation of other ES due to the increased erosion of trails. 
TABLE 3. Important ES identified by stakeholders for nature-based tourism in Lofoten and perceived climate indices and effects due to climate change.

\begin{tabular}{|c|c|c|}
\hline $\begin{array}{c}\text { Ecosystem services (subsystems in } \\
\text { parentheses) }\end{array}$ & $\begin{array}{c}\text { Perceived climate indices (other indices in } \\
\text { parentheses) }\end{array}$ & Perceived effects due to climate changes \\
\hline $\begin{array}{l}\text { Iconic view: mountains, sea, northern } \\
\text { lights, midnight sun, pastoral landscape, } \\
\text { flat sea, good weather } \\
\text { (All subsystems) }\end{array}$ & $\begin{array}{l}\text { Temperature of the air; bad weather; } \\
\text { persistent precipitation ( } 20 \text { of } 30 \text { days); } \\
\text { wind }\end{array}$ & $\begin{array}{l}\text { Less attractive view; overgrowing/forest; } \\
\text { loss of income from daily booking }\end{array}$ \\
\hline $\begin{array}{l}\text { Cod (skrei) and the Lofoten fisheries } \\
\text { including stockfish and cultural } \\
\text { landscape; (fishing tourism, cultural } \\
\text { heritage, and local food) }\end{array}$ & $\begin{array}{l}\text { Temperature of the sea; bad weather; } \\
\text { wind }>12 \mathrm{~m} \mathrm{~s}^{-1} \text {; persistent } \\
\text { precipitation }\end{array}$ & $\begin{array}{l}\text { Changing migration pattern for the cod; } \\
\text { canceled fishing trips because of wind; } \\
\text { changed booking behavior; loss of } \\
\text { attractiveness/visitors }\end{array}$ \\
\hline $\begin{array}{l}\text { Other species/biodiversity (halibut, whale, } \\
\text { seal, eagle, other birds, and fish) (sea } \\
\text { safari, bird watching, phototourism, } \\
\text { and local food) }\end{array}$ & $\begin{array}{l}\text { Temperature of the sea/air; bad weather; } \\
\text { wind }>12 \mathrm{~m} \mathrm{~s}^{-1} \text { (overfishing/ } \\
\text { overextraction/pollution) }\end{array}$ & $\begin{array}{l}\text { Loss of biodiversity; loss of species; loss } \\
\text { of attractiveness/visitors }\end{array}$ \\
\hline $\begin{array}{l}\text { Snow ( }>30 \mathrm{~cm} \text { of snow cover) (snow- } \\
\text { based activities: skiing; snowshoe } \\
\text { guiding) }\end{array}$ & Temperature & $\begin{array}{l}\text { Shorter ski season; loss of income } \\
\text { because of cancellations; loss of } \\
\text { attractiveness/visitors }\end{array}$ \\
\hline $\begin{array}{l}\text { Cultural heritage/landscape (fishing } \\
\text { villages, fishermen cabins, etc.) } \\
\text { (cultural heritage; all subsystems as a } \\
\text { backdrop) }\end{array}$ & $\begin{array}{l}\text { Bad weather; storms; precipitation; } \\
\text { temperature (sea level) }\end{array}$ & $\begin{array}{l}\text { Flooding and property damage; moisture } \\
\text { damage; adjustments resulting in less } \\
\text { authentic landscapes; increased costs } \\
\text { (public requirements and more } \\
\text { frequent maintenance) }\end{array}$ \\
\hline $\begin{array}{l}\text { Infrastructure (bridges, boats, tunnels, } \\
\text { airports, and roads) and regularity (all } \\
\text { subsystems) }\end{array}$ & $\begin{array}{l}\text { Wind (storms); precipitation; temperature } \\
\quad(\text { sea level) }\end{array}$ & $\begin{array}{l}\text { Less regularity and closed roads/bridges; } \\
\text { loss of infrastructure/damages; } \\
\text { avalanches, rockfalls, damage; loss of } \\
\text { income because of cancellations }\end{array}$ \\
\hline $\begin{array}{l}\text { Trails in alpine and steep terrain and } \\
\text { rangeland (hiking; climbing) }\end{array}$ & $\begin{array}{l}\text { Bad weather; precipitation; wind; } \\
\text { temperature }\end{array}$ & $\begin{array}{l}\text { Risk of rockslides, erosion, and } \\
\text { degradation; canceling because of bad } \\
\text { weather; loss of biodiversity; erosion of } \\
\text { trails; loss of attractiveness }\end{array}$ \\
\hline $\begin{array}{l}\text { Predictable weather (flat water) (all } \\
\text { subsystems) }\end{array}$ & Wind precipitation & $\begin{array}{l}\text { Canceling because of bad weather; loss of } \\
\text { income from daily bookings }\end{array}$ \\
\hline $\begin{array}{l}\text { View below sea surface [sea-based } \\
\text { activities (diving)] }\end{array}$ & Temperature of the sea; (pollution) & $\begin{array}{l}\text { Loss of view and attractiveness; algal } \\
\text { blooms }\end{array}$ \\
\hline
\end{tabular}

We have analyzed 10 high-resolution regional $1 \mathrm{~km} \times 1 \mathrm{~km}$ grids (see Wong et al. 2016) on future climate change impacts on specific parameters, identified by the practitioners, that will potentially influence relevant ES for tourism activities in Lofoten (see Table 3). Based on the authors' assessment of the climate parameters' relative importance for products and services offered at the destination, we have analyzed seasonal changes in projected temperature, precipitation amount (snow, sleet, and rain), long periods with precipitation (blocked weather systems), and snow depth for the six municipalities of Lofoten. ${ }^{11}$ Wind has obviously also been identified as very important by the stakeholders, but research has not shown significant influence of human-induced climate change on storminess (Vautard et al. 2019).

The Norwegian government guideline on climate change adaptation (Ministry of Climate and Environment 2013) recommends precaution should be applied when considering the

\footnotetext{
${ }^{11}$ More details about the climate model analyses will be presented in detail in S. Mayer et al. (2021, unpublished manuscript).
}

effects of climate change in decision-making. Thus, we have prioritized the analysis of climate model projections based on the high emission scenario with the representative concentration pathway 8.5 (RCP8.5), which assumes that greenhouse gas emissions due to anthropogenic activity will increase at the same rate as that observed since the 1960s. The plausibility of this scenario relative to others has not been assessed, although the authors believe it to be a potentially important topic for further scrutiny elsewhere.

Several stakeholders professed that they very rarely cancel activities due to precipitation alone. However, drop-ins decline with increased precipitation, stronger winds, or bad weather forecasts. Together with s- 1 and s-2, we have compared daily sales during the summer season 2019 with reported weather for the same period and found indications that there is a correlation between what is defined as "bad weather" and "bad sales" and cancellations. The category "bad weather" was defined to indicate more than $8 \mathrm{~mm}$ of rain per day, while wind strength of more than $12 \mathrm{~m} \mathrm{~s}^{-1}$ was identified as a critical level for security reasons among stakeholders. Increased precipitation as an effect of climate change 
would potentially be a real threat to tourism actors, as we can assume less tourism demand for outdoor activities.

Attracting more winter tourists is an important strategy for Lofoten as a year-round destination. Activities such as alpine skiing (backcountry/randonnée) and snowshoe hiking are obviously dependent on snow. Therefore, the combination of temperature and precipitation matters during both winter and spring months. Based on the assumption that less snow cover will influence future nature-based tourism in Lofoten, snow coverage models showing areal mean over Lofoten for grid points above $300-\mathrm{m}$ altitude and a snow depth of $30 \mathrm{~cm}$ (defined by stakeholders and researchers with skiing experience) was prepared for this study (S. Mayer et al. 2021, unpublished manuscript). Models for mean temperature change for Lofoten (S. Mayer et al. 2021, unpublished manuscript) complement the picture concerning the most prominent effects on ES that are important for nature-based tourism in the region.

Following an RCP8.5 emission pathway, the different future climate scenarios for Lofoten based on the stakeholders' concerns about future climate change show that we can annually expect

- on average seven days more with a precipitation intensity higher than $8 \mathrm{~mm} \mathrm{day}^{-1}$ by the end of this century relative to 1971-2000 (strongest increase during fall),

- significant increase in total precipitation (almost 25\%),

- significantly higher temperatures for all seasons, that is, a mean increase for $2031-60$ of $2.5^{\circ}$ and a $4.5^{\circ} \mathrm{C}$ increase for 2071-2100,

- that precipitation in the mountains will fall more often as rain instead of snow during winter and spring, and

- that snow depth beyond $30 \mathrm{~cm}$ will be rare in the region, even in a shorter time perspective (2031-60); however, single winters with a lot of snow will still be possible at elevations from $500 \mathrm{~m}$ above sea level.

Even if we tailored future climate models on the basis of impact categories assessed by the stakeholders, the modeling of snow conditions, precipitation/bad weather and temperatures were based on a limited data source. Unfortunately, because of COVID-19, we were not able to do a last workshop to present, discuss, and possibly adjust our modeling of scenarios.

\section{Analysis and discussions: Diversity, adaptive capacity, resilience, and transformative capacity of nature- based tourism}

Our findings from Lofoten underline the nature-based tourism sector's dependence on many related tangible and intangible ES. The great number of ES valued as important reflects the wide range of activities offered in the region (Kaltenborn et al. 2019). This diversity indicates a high level of risk-spreading and thus a resilient system (e.g., Wyss et al. 2014b). Even if one or two of the subsystems experience stressors that necessitate adaptation (Béné and Doyen 2018), nature-based tourism is likely to remain a relatively stable overall system.
One illustrating example brought up by s-1 and s- 2 was how sea safaris taking place in Lofoten responded to the situation in which, 10-15 years ago, the key species, orcas (Orcinus orca), all but disappeared from Lofoten due to changes in the migration patterns of herring (Clupea harengus). Instead of shutting down or relocating, the actors' response was to shift from orcas to sea eagles (Haliaeetus albicilla) as the main attraction.

The observed high perception among stakeholders about their adaptive capacity to present changes and risks are in line with other research findings (Scott et al. 2012; Reisinger et al. 2014). This is often explained as an outcome of the sector's ability to cope with macroscale shocks mentioned in section 2 a. In terms of the high perceived adaptive capacity to unpredictability among practitioners in nature-based tourism in Lofoten, we argue that much of this is connected to a culturally and historically embedded resilience where being able to cope with above-average variability is the norm (Hovelsrud et al. 2018), a resilience that is closely tied to the very essential reason for staying - the in-migration of skrei. The changing seasons, unpredictable weather situation, and the remoteness of the region contribute to the foundation for a sense of coping. "We will endure" (vi står han $a v$ ) is a common phrase used in the coastal regions of northern Norway, pointing to an ability to withstand, adapt, cope, and survive - no matter what. This could be seen as a sociocultural manifestation of resilience based on heritage and practice-based learning from generations of fishermen, farmer-fishermen and seafarers risking their lives every day due to the unpredictable weather, and of women running the communities, farms, and welfare services in the longterm absence of the men.

The indication of difference in adaptive capacity between fishing and sea-based tourism and other subsystems found in Lofoten can be explained by the fishing tourism being less diverse, offering only one or a few activities or assortments of activities, and with a deeper path dependency related to investments in expensive equipment. Thus, they are less flexible and more dependent on good weather due to the risk to equipment and to the customer, meaning that in rough conditions, they have to cancel rentals. As also suggested by some of the stakeholders, another explanation could be that the guides and operators in other subsystems have acquired competences that ensure a higher adaptive capacity. For instance, it is common that they are educated as nature guides, tourist operators, or business entrepreneurs, often collaborating in business networks with others. Operators in fishing tourism, on the other hand, are more often former/present professional fishermen with inherited knowledge about fishing and seamanship, including a deep respect for the unpredictable forces of nature. But they may lack the entrepreneurial proactiveness of a nature guide who has learned that coping with constant change is the first step in making their livelihood from outdoor tourism activities. This difference first and foremost manifests itself in the fact that if the former fisherman cannot go out to fish, he does what has always been done-he postpones-while the professional guide will seek alternative activities. 
We find this insight intriguing, as on the surface of things it reveals a curious contradiction. Tourism operators whose modus vivendi is most closely related to traditional fisheries-from where the self-proclaimed resilience to dramatic changes is derived-also express a lack of preparedness for change. Thus, the resilience that they nevertheless express is not necessarily specific nor refers to the subsystem of fishing tourism or to specific ES (skrei). It rather refers to a general collective capability to withstand change over time without "bailing out," that is, moving elsewhere. As for s-15, the combination of a secure income from the fisheries and turning to other segments than the traditional "fishing tourists" can be interpreted as an adaptation strategy aiming to reduce vulnerability related to unpredictable weather, but also to achieve higher revenues from less price-sensitive customers. This also chimes well with the broader conceptualization of general resilience (Folke et al. 2010; Carr 2019) where active participants influence resilience through agency and adaptive capacity. Therefore, fishing tourism itself could be seen as but one of many options in a flexible system where, over generations and centuries, people in Lofoten have not only survived but thrived, and, most importantly, not left for some other place to live (see Dale 2011 for ethnographic descriptions of the relationship between fisheries and place-based identity construction in Lofoten). Curiously, this idea about a general resilience ( $v i$ står han $a v$ ) remains even though there is and has always been an influx and outflux of people to and from the region (Antonsen 2011).

Most of the practitioners perceive themselves as highly adaptive in the short run, often by referring to personal experiences of weather (see also Wyss et al. 2014a). Still, they find it hard, and even irrelevant, to "look too far into the future," beyond the lifetime of their own business. This aligns with Hopkins's (2013) findings (see section 1). Even if our models were scaled down to Lofoten, the uncertainty of the models and of looking so far into the future lead the stakeholders to talk about experienced weather, or simply answering as s-14 did when he was shown our tailored scenarios: "If the snow disappears during our lifetime, we will simply have to relocate."

Aligned with findings in resilience and adaptation literature in general (e.g., Luthe and Wyss 2014; Westskog et al. 2017), several of the stakeholders in Lofoten pointed out that their adaptive capacity relies on various factors beyond their own control: Similar to findings of Turton et al. (2010), we found a shared sense among the stakeholders that climate change-related issues are expected to be handled by the public sector, and that what stakeholders perceived as adaptions to climate change were often actually adaptions to climate policy [Turton et al. (2010), as summarized by Scott and Becken (2010, p. 293)]. S-5 pointed out that lack of governance and adaption strategies by local, regional, and national authorities are of the greatest risks: ". . . the changes are coming faster than the adaptions." Three stakeholders brought up climate policy as an even greater potential threat to the tourism system than climate change itself. For instance-as confirmed by a recent Solberg Cabinet White Paper on climate policy for 2021-30
(Ministry of Climate and Environment 2021) - rising traveling costs due to increased taxes on emissions are to be expected. According to stakeholders, this policy is likely to reduce the competitiveness of high-cost destinations like Lofoten. Also, geopolitics and climate change at other destinations were brought up as factors that are likely to influence their market position. In alignment with other research findings (Ciscar et al. 2011), potentially positive outcomes from increased tourism demand for destinations at higher latitudes (e.g., in Scandinavia) due to climate-induced heat or drought at destinations at lower latitudes were brought up in three interviews. According to Scott and Becken (2010), the kind of perceptions mentioned above illustrate a limited understanding of climate change adaption by tourism stakeholders, and that such understandings also represent an important barrier to climate change in tourism decision-making. These themes are also discussed in literature and policy material on transboundary risks and impact chains (e.g., Lidskog et al. 2011; Fritzsche et al. 2017; Benzie et al. 2019; Booth et al. 2020).

\section{Conclusions and challenges for further research}

Our analysis has shown that practitioners in nature-based tourism are concerned to a certain extent that future climate change-induced increased temperatures might lead to more bad weather, a decline in snow cover, increased erosion, and higher sea levels, and that more extreme weather events will impact income and infrastructure. Their concerns are related to a broad set of ecosystem services (ES), perceived to be crucial for tourism, including biodiversity, cultural heritage, cultural identity, and aesthetic inspiration. Despite concerns, the nature-based tourism industry in Lofoten pre-COVID-19 was perceived by stakeholders as adaptable, resilient, and flexible due to the utilization of a great variety of cultural, provisional, and regulating ES. Resilience and flexibility were linked to the great diversity of ES and ES-based products and services, and adaptability to a perception of a socially and culturally maintained capacity for coping with the unpredictable. The system had a wide latitude in terms of possible adaptation strategies in meeting minor and larger challenges.

Different assessments provided by stakeholders in Lofoten on the potential impacts on their activities - if not of future climate change alone, but more of the generally unpredictable situation-speak volumes about the future capacity to adapt and reaffirm the notion of resilience. The reference from stakeholders to general resilience, in tune with the definition from Folke et al. (2010), shows that nature-based tourism in Lofoten is but a number of potential adaptation strategies for coping. Thus, the adaptive capacity of individual actors in the sector both refers to and influences an overall resilience in the communities of Lofoten that extends beyond tourism.

One important take-home message relevant for other destinations is that the possibility of utilizing multiple ES is no guarantee for that the potential loss of any one specific ES would not weaken an overall resilience. For instance, if the skrei had disappeared from the waters of Lofoten, we argue that this loss would negatively influence the overall resilience 
of the system upon which nature-based tourism in Lofoten has thrived. This is not because most of the tourism actors have this particular species as a main source for experiences, but because the historic and cultural identity and the authenticity of the Lofoten islands are inextricably linked to the skrei. The fact that the migration patterns of the skrei might change due to climate change should not be underestimated as a threat to future resilience of the system. General lessons learned from this example are that despite a general perspective to resilience, some ES cannot simply be replaced, and that the complexity and interdependence of ES should not be underestimated in understanding resilience of nature-based tourism.

Today, tourism destinations worldwide find themselves closer to crossing a threshold where recovery is perhaps impossible. COVID-19 has exposed the vulnerability of the global tourism system, illustrating how the central characteristic of tourism - traveling - is a potential threat to its own resilience. The politically decided restrictions on traveling that followed COVID-19 have laid bare the urgent need for transformation in the industry (Gössling et al. 2020). The effects caused by COVID-19 may prove to be an example of how the future of tourism relies not only on adaptive capacities and system resilience but also on the actors' and systems' ability to transform. Also, tourism's contribution to global emissions is of major concern (Dubois and Ceron 2006; Scott and Becken 2010; Scott et al. 2012; Gössling et al. 2013; Scott et al. 2016; Gössling and Higham 2020). In the wake of the vulnerability revealed by COVID-19 and the obligations contained in the Paris Agreement on reducing global emissions, we argue that a transition toward a more sustainable tourism industry (on both climatic, environmental, social, and economic parameters) could reveal a more resilient tourism system. In line with the understanding of a general (inclusive) resilience capability (Folke et al. 2010), we assess that nature-based tourism destinations similar to Lofoten are likely to have a level of transformability that could ensure future resilience and sustainability, if not for the tourism sector in its current form, but for the communities where tourism takes place. Another take-home message from this study would thus be that the way a tourist destination best increases resilience would be to increase one's flexibility with regard to dependency on specific ES.

Diverse destinations, characterized by the utilization of a wide set of ES, and where the tourism industry does coexist with other industries in a vibrant community, can contribute to making tourism systems more flexible and capable of facing a future in which transformation seems more likely than "building back." One reason for this is that stakeholders have not invested heavily in hard infrastructure like ski lifts or cruise boats tailored for specific market segments and ES. It will be easier to transform when the path is not predetermined by previous investments or dependent on only one or a few ES. Likewise, activities offered at nature-based destinations are often low-carbon and high-value products, attracting visitors that can thereby contribute to build sustainable local communities and to the shift from volume to value creation. The remoteness and small-scale accommodations may even turn out to be a transformative ability, given that the postCOVID-19 travelers might potentially seek more rural destinations and smaller accommodations to avoid crowding. Finally, the ongoing travel restrictions might be an opportunity to change future travel patterns. A shift in orientation toward markets closer to the destination would contribute to a lower carbon footprint and to a reduced dependency on the state of global affairs. New travel patterns might favor destinations that can offer a variety of activities and experiences, as a more sustainable tourism sector should develop strategies to facilitate for longer but fewer travels for the average customer.

As shown above, stakeholders do report of changes in tourists' preferences and behavior. Research has argued for a greater degree of attention on the tourists' perception, since they are the ones with the largest capacity to adapt to changes in climate, mobility costs, or politics, simply by substituting destinations, seasons, and activities (Gössling et al. 2012; Scott et al. 2016). Tourists' adaptive capacity, awareness of, and response to climate change and climate policy are therefore important assessments to include when planning to meet future challenges, and thus an interesting topic for further studies.

However, if the tourism sector is to put new sustainable models into action, their strategies must reflect other regimes than those of volume-based growth. It turns out that the tourism sector's understanding of climate variability is often defined within a broader sustainability discussion to which job creation and economic sustainability also belong (Scott and Becken 2010) and where climate issues are understood either as imposing variations on their capacity or as changes so far ahead in time that they are of minor concern for day-to-day operations. The shift from volume to value creation has been highlighted as the roadmap to sustainable tourism but has been difficult to implement due to a variety of obstacles (Gössling and Higham 2020). It is crucial for climate policy and the tourism sector to overcome these obstacles and they are therefore important topics for further research and for sustainable tourism.

Acknowledgments. This paper is based on research in the ClimTour project funded by the Research Council of Norway (Grant 281006). The recipient of the grant, and project manager, is Western Norway Research Institute.

Data availability statement. Climate datasets will be included in S. Mayer et al. (2021, unpublished manuscript). Social science data will be stored and secured in line with GDPR regulations. The availability of these data will be subject to informant acceptance in accordance with ethical standards.

\section{REFERENCES}

Antonsen, K. M., 2011: Å velge bosted i Lofoten: En diskursanalyse av folkelige fortellinger om bostedsvalg og hverdagsliv. Ph.D. thesis, Geografisk Institutt, Norwegian University of Science and Technology, 274 pp., http://hdl.handle.net/11250/ 265367. 
_ , and A. Enger, 2020: Gjesteundersøkelse 2019 (Guest survey). Nordland Research Institute NF-Rep., 58 pp., https:// hdl.handle.net/11250/2725905.

Becken, S., 2013: Developing a framework for assessing resilience of tourism sub-systems to climatic factors. Ann. Tourism Res., 43, 506-528, https://doi.org/10.1016/j.annals.2013.06.002.

Béné, C., and L. Doyen, 2018: From resistance to transformation: A generic metric of resilience through viability. Earth's Future, 6, 979-996, https://doi.org/10.1002/2017EF000660.

Benzie, M., T. R. Carter, H. Carlsen, and R. Taylor, 2019: Crossborder climate change impacts: Implications for the European Union. Reg. Environ. Change, 19, 763-776, https://doi. org/10.1007/s10113-018-1436-1.

Bertelsen, R., and P. Urbańczyk, 1988: Two perspectives on Vågan in Lofoten. Acta Boreal., 5, 98-110, https://doi.org/10. 1080/08003838808580358.

Biggs, D., C. M. Hall, and N. Stoeckl, 2012: The resilience of formal and informal tourism enterprises to disaster: Reef tourism in Phuket, Thailand. J. Sustainable Tourism, 20, 645-665, https://doi.org/10.1080/09669582.2011.630080.

Bjørkan, M., and S. Veland, 2019: Beyond consensus: Perceptions of risk from petroleum developments in Lofoten, Vesterålen and Senja, Norway. ICES J. Mar. Sci., 76, 1393-1403, https:// doi.org/10.1093/icesjms/fsz056.

Booth, L., K. Fleming, J. Abad, L. A. Schueller, M. Leone, A. Scolobig, and A. Baills, 2020: Simulating synergies between climate change adaptation and disaster risk reduction stakeholders to improve management of transboundary disasters in Europe. Int. J. Disaster Risk Reduct., 49, 101668, https:// doi.org/10.1016/j.ijdrr.2020.101668.

Carr, E. R., 2019: Properties and projects: Reconciling resilience and transformation for adaptation and development. World Dev., 122, 70-84, https://doi.org/10.1016/j.worlddev.2019.05. 011.

Cash, D., W. Clark, F. Alcock, N. Dickson, N. Eckley, and J. Jäger, 2002: Salience, credibility, legitimacy and boundaries: Linking research, assessment and decision making. Harvard University John F. Kennedy School of Government Working Papers Series, 24 pp., https://doi.org/10.2139/ssrn.372280.

Chan, K. M. A., T. Satterfield, and J. Goldstein, 2012: Rethinking ecosystem services to better address and navigate cultural values. Ecol. Econ., 74, 8-18, https://doi.org/10.1016/j. ecolecon.2011.11.011.

Church, A., T. Coles, and R. Fish, 2017: Tourism in sub-global assessments of ecosystem services. J. Sustainable Tourism, 25, 1529-1546, https://doi.org/10.1080/09669582.2017.1291649.

Ciscar, J.-C., and Coauthors, 2011: Physical and economic consequences of climate change in Europe. Proc. Natl. Acad. Sci. USA, 108, 2678-2683, https://doi.org/10.1073/pnas.1011612108.

Cole, S. G., and Coauthors, 2016: Arctic games: An analytical framework for identifying options for sustainable natural resource governance. Polar J., 6, 30-50, https://doi.org/10. 1080/2154896X.2016.1171001.

Dale, B., 2011: Securing a contingent future: How threats, risks and identity matter in the debate over petroleum development in Lofoten, Norway. Ph.D. thesis, Department of Sociology, Political Science and Community Planning, University of Troms $\varnothing, 259$ pp., https://hdl.handle.net/10037/4150.

, 2016: Governing resources, governing mentalities. Petroleum and the Norwegian integrated ecosystem-based management plan for the Barents and Lofoten Seas in 2011. $J$. Extr. Ind. Soc., 3, 9-16, https://doi.org/10.1016/j.exis.2015.10. 002.
— , and B. Kristoffersen, 2018: Post-petroleum security in a changing Arctic: Narratives and trajectories towards viable futures. Arct. Rev. Law Polit., 9, 244-261, https://doi.org/10. 23865/arctic.v9.1251.

—, S. Veland, and A. M. Hansen, 2018: Petroleum as a challenge to Arctic societies: Ontological security and the oildriven 'push to the north.' J. Extr. Ind. Soc., 6, 367-377, https://doi.org/10.1016/j.exis.2018.10.002.

Dannevig, H., and C. Aall, 2015: The regional level as boundary organization? An analysis of climate change adaptation governance in Norway. Environ. Sci. Policy, 54, 168-175, https:// doi.org/10.1016/j.envsci.2015.07.001.

de Groot, R. S., R. Alkemade, L. Braat, L. Hein, and L. Willemen, 2010: Challenges in integrating the concept of ecosystem services and values in landscape planning, management and decision making. Ecol. Complex., 7, 260-272, https://doi. org/10.1016/j.ecocom.2009.10.006.

Dubois, G., and J. P. Ceron, 2006: Tourism/leisure greenhouse gas emissions forecasts for 2050: Factors for change in France. J. Sustainable Tourism, 14, 172-191, https://doi.org/10.1080/ 09669580608669051.

Duffy, R., 2015: Nature-based tourism and neoliberalism: Concealing contradictions. Tourism Geogr., 17, 529-543, https:// doi.org/10.1080/14616688.2015.1053972.

Fennell, D. A., 2015: Ecotourism. Routledge, 336 pp.

Folke, C., 2006: Resilience: The emergence of a perspective for social-ecological systems analyses. Global Environ. Change, 16, 253-267, https://doi.org/10.1016/j.gloenvcha.2006.04.002.

— S. R. Carpenter, B. Walker, M. Scheffer, T. Chapin, and J. Rockström, 2010: Resilience thinking: Integrating resilience, adaptability and transformability. Ecol. Soc., 15, 20, https:/ doi.org/10.5751/ES-03610-150420.

Fritzsche, K., S. Schneiderbauer, P. Bubeck, S. Kienberger, M. Buth, M. Zebisch, and W. Kahlenborn, 2017: The vulnerability sourcebook: Concept and guidelines for standardised vulnerability assessments. Deutsche Gesellschaft für Internationale Zusammenarbeit Doc., 180 pp.

Gildestad, I. M., H. Dannevig, R. Steiger, and C. Aall, 2017: Konsekvensar av klimaendringar for norske skianlegg. Vestlandsforskning Vestlandsfroskningsrapport 10/2017, 34 pp., https:// www.vestforsk.no/sites/default/files/2017-12/vf-rapport \%20102017\%20Konsekvensar\%20av\%20klimaendringar\%20for \%20 norske\%20skianlegg_0.pdf.

Goodwin, H., 1996: In pursuit of ecotourism. Biodivers. Conserv., 5, 277-291, https://doi.org/10.1007/BF00051774.

Gössling, S., and J. Higham, 2020: The low-carbon imperative: Destination management under urgent climate change. J. Travel Res., 60, 1167-1179, https://doi.org/10.1177/0047287520933679.

— D. Scott, C. M. Hall, J.-P. Ceron, and G. Dubois, 2012: Consumer behaviour and demand response of tourists to climate change. Ann. Tourism Res., 39, 36-58, https://doi.org/10.1016/ j.annals.2011.11.002.

,-- , and,- 2013 : Challenges of tourism in a low-carbon economy. Wiley Interdiscip. Rev.: Climate Change, 4, 525-538, https://doi.org/10.1002/wcc.243.

,-- , and -2020 : Pandemics, tourism and global change: A rapid assessment of COVID-19. J. Sustainable Tourism, 29, 1-20, https://doi.org/10.1080/09669582.2020.1758708.

Gunderson, L. H., and C. S. Holling, Eds., 2002: Panarchy: Understanding Transformations in Human and Natural Systems. Island Press, 507 pp. 
Hall, C. M., 2001: Trends in ocean and coastal tourism: The end of the last frontier? Ocean Coastal Manage., 44, 601-618, https://doi.org/10.1016/S0964-5691(01)00071-0.

- 2010: Tourism, biodiversity and global environmental change. Tourism and Global Environmental Change: Ecological, Social, Economic and Political Interrelationships, S. Gössling and C. M. Hall., Eds., Routledge, 211-226.

Hopkins, D., 2013: The perceived risks of local climate change in Queenstown, New Zealand. Curr. Issues Tourism, 18, 947965, https://doi.org/10.1080/13683500.2013.776022.

Houston, J., 2002: The economic value of beaches: A 2002 update. Shore Beach, 70, 9-12.

Hovelsrud, G. K., M. Karlsson, and J. Olsen, 2018: Prepared and flexible: Local adaptation strategies for avalanche risk. Cogent Soc. Sci., 4, 1460899, https://doi.org/10.1080/23311886. 2018.1460899.

Innovasjon Norge, 2018: Turistunders $\varnothing$ kelsen 2018. Regionrapporter Doc., 53 pp.

IPCC, 2018: Summary for policymakers. Global Warming of $1.5^{\circ} \mathrm{C}, \mathrm{V}$. Masson-Delmotte et al., Eds., Cambridge University Press, 32 pp., https://www.ipcc.ch/site/assets/uploads/sites/ 2/2019/05/SR15_SPM_version_report_LR.pdf.

Jentoft, S., and T. Kristoffersen, 1989: Fisheries co-management: The case of the Lofoten fishery. Hum. Organ., 48, 355-365, https://doi.org/10.17730/humo.48.4.k045637kv290u886.

Johnsen, J. P., and J. Vik, 2013: Pushed or pulled? Understanding fishery exit in a welfare society context. Marit. Stud., 12, 4, https://doi.org/10.1186/2212-9790-12-4.

Kaltenborn, B. P., E. F. Kaltenborn, and J. D. C. Linnell, 2019: "It's all about the scenery": Tourists' perceptions of cultural ecosystem services in the Lofoten Islands, Norway. Arctic, 72 (1), 1-102, https://doi.org/10.14430/arctic67944.

Karlsson, M., and B. Dale, 2019: 'It belongs to the world'. Oil, conservation and futures in the making in Lofoten, Norway. Environ. Plann., 37C, 1452-1470, https://doi.org/10.1177/ 2399654419835828.

Kelman, I., T. Luthe, R. Wyss, S. H. Tørnblad, Y. Evers, M. M. Curran, R. J. Williams, and E. L. Berlow, 2016: Social network analysis and qualitative interviews for assessing geographic characteristics of tourism business networks. PLOS ONE, 11, e0156028, https://doi.org/10.1371/journal.pone.0156028.

Lidskog, R., Y. Uggla, and L. Soneryd, 2011: Making transboundary risks governable: Reducing complexity, constructing spatial identity, and ascribing capabilities. Ambio, 40, 111-120, https://doi.org/10.1007/s13280-010-0123-3.

Linnenluecke, M. E., 2015: Resilience in business and management research: A review of influential publications and research agenda. Int. J. Manage. Rev., 19, 4-30, https://doi. org/10.1111/ijmr.12076.

Luthe, T., and R. Wyss, 2014: Assessing and planning resilience in tourism. Tourism Manage., 44, 161-163, https://doi.org/10. 1016/j.tourman.2014.03.011.

Manring, S. L., 2014: The role of universities in developing interdisciplinary action research collaborations to understand and manage resilient social-ecological systems. J. Clean. Prod., 64, 125-135, https://doi.org/10.1016/j.jclepro.2013.07.010.

Milcu, A. I., J. Hanspach, D. Abson, and J. Fischer, 2013: Cultural ecosystem services: A literature review and prospects for future research. Ecol. Soc., 18, 44, https://doi.org/10.5751/ES05790-180344.

Miller, F., and Coauthors, 2010: Resilience and vulnerability: Complementary or conflicting concepts? Ecol. Soc., 15, 11, https://doi.org/10.5751/ES-03378-150311.
Ministry of Climate and Environment, 2013: Climate change adaptation in Norway. Melding til Stortinget 33 (2012-2013), 108 pp.

Ministry of Climate and Environment, 2021: Klimaplan for 2021-2030. Melding til Stortinget 13 (2020-2021), 208 pp.

Moreno, A., and S. Becken, 2009: A climate change vulnerability assessment methodology for coastal tourism. J. Sustainable Tourism, 17, 473-488, https://doi.org/10.1080/09669580802651681.

Nelson, D. R., W. N. Adger, and K. Brown, 2007: Adaption to environmental change: Contribution of a resilience framework. Annu. Rev. Environ. Resour., 32, 395-419, https://doi. org/10.1146/annurev.energy.32.051807.090348.

Newsome, D., S. A. Moore, and R. K. Dowling, 2013: Natural Area Tourism: Ecology, Impacts and Management. 2nd ed. Channel View Publications, 457 pp.

Norström, A. V., and C. Cvitanovic, 2020: Principles for knowledge co-production in sustainability research. Nat. Sustainability, 3, 182-190, https://oi.org/10.1038/s41893-019-0448-2.

Prebensen, N. K., J. Vitters $\varnothing$, and T. I. Dahl, 2013: Value co-creation significance of tourist resources. Ann. Tourism Res., 42, 240-261, https://doi.org/10.1016/j.annals.2013.01.012.

Reid, W. V., and Coauthors, 2005: Ecosystems and human wellbeing: Synthesis. United Nations Millennium Ecosystem Assessment Doc., 137 pp., https://wedocs.unep.org/20.500. $11822 / 8701$.

Reisinger, A., and Coauthors, 2014: Australasia. Climate Change 2014: Impacts, Adaptation, and Vulnerability, Part B: Regional Aspects, V. R. Barros and D. Field, Eds., Cambridge University Press, 1371-1438, https://www.ipcc.ch/site/assets/uploads/ 2018/02/WGIIAR5-Chap25_FINAL.pdf.

Scott, D., and S. Becken, 2010: Adapting to climate change and climate policy: Progress, problems and potentials. J. Sustainable Tourism, 18, 283-295, https://doi.org/10.1080/09669581003668540. _ , S. Gössling, and C. M. Hall, 2012: International tourism and climate change. Wiley Interdiscip. Rev.: Climate Change, 3, 213-232, https://doi.org/10.1002/wcc.165.

_ C. M. Hall, and S. Gössling, 2016: A review of the IPCC Fifth Assessment and implications for tourism sector climate resilience and decarbonization. J. Sustainable Tourism, 24, 8-30, https://doi.org/10.1080/09669582.2015.1062021.

Smith, B. W., E. M. Tooley, P. J. Christopher, and V. S. Kay, 2009: Resilience as the ability to bounce back from stress: A neglected personal resource. J. Posit. Psychol., 5, 166-176, https://doi.org/10.1080/17439760.2010.482186.

Steiger, R., D. Scott, B. Abegg, M. Pons, and C. Aall, 2017: A critical review of climate change risk for ski tourism. Curr. Issues Tourism, 22, 1343-1379, https://doi.org/10.1080/13683500.2017. 1410110.

Sundby, S., and O. Nakken, 2008: Spatial shifts in spawning habitats of Arcto-Norwegian cod related to multidecadal climate oscillations and climate change. ICES J. Mar. Sci., 65, 953962, https://doi.org/10.1093/icesjms/fsn085.

Turton, S., T. Dickson, W. Hadwen, B. Jorgensen, T. Pham, D. Simmons, P. Tremblay, and R. Wilson, 2010: Developing an approach for tourism climate change assessment: Evidence from four contrasting Australian case studies. J. Sustainable Tourism, 18, 429-447, https://doi.org/10.1080/09669581003639814.

Vautard, R., and Coauthors, 2019: Human influence on European winter wind storms such as those of January 2018. Earth Syst. Dyn., 10, 271-286, https://doi.org/10.5194/esd-10-271-2019.

Walker, B., C. S. Holling, S. R. Carpenter, and A. Kinzig, 2004: Resilience, adaptability and transformability in social-ecological 
systems. Ecol. Soc., 9, 5, https://doi.org/10.5751/ES-00650090205.

Weber, K., 2001: Outdoor adventure tourism: A review of research approaches. Ann. Tourism Res., 28, 360-377, https:// doi.org/10.1016/S0160-7383(00)00051-7.

Westskog, H., G. K. Hovelsrud, and G. Sundqvist, 2017: How to make local context matter in national advice: Towards adaptive comanagement in Norwegian climate adaptation. Wea. Climate Soc., 9, 267-283, https://doi.org/10.1175/WCAS-D-160063.1.

Wong, W. K., I. Haddeland, D. Lawrence, and S. Beldring, 2016: Gridded $1 \times 1 \mathrm{~km}$ climate and hydrological projections for Norway. Norwegian Water Resources and Energy Directorate Rep. 59, 25 pp., https://publikasjoner.nve.no/rapport/2016/ rapport2016_59.pdf.

World Tourism Organization, 2014: Global report on adventure tourism. United Nations WTO Rep., 85 pp., https://doi.org/ $10.18111 / 9789284416622$.
World Travel and Tourism Council, 2019a: Travel \& tourismBenchmarking research trends 2019: How does travel \& tourism compare to other sectors? WTTC Doc., 9 pp., https:// wttc.org/Portals/0/Documents/Reports/2019/Benchmarking\%20 Trends\%20Report\%202019.pdf?ver=2021-02-25-182807-540.

- 2019b: The economic impact of global wildlife tourism: Travel \& tourism as an economic tool for the protection of wildlife. WTTC Doc., 17 pp., https://wttc.org/Portals/0/ Documents/Reports/2019/Sustainable\%20Growth-Economic\% 20Impact\%20of\%20Global\%20Wildlife\%20Tourism-Aug\%20 2019.pdf?ver=2021-02-25-182802-167.

Wyss, R., B. Abegg, and T. Luthe, 2014a: Perceptions of climate change in a tourism governance context. Tourism Manage. Perspect., 11, 69-76, https://doi.org/10.1016/j.tmp.2014.04.004.

- T. Tuthe, and B. Abegg, 2014b: Building resilience to climate change-The role of cooperation in alpine tourism networks. Local Environ., 20, 908-922, https://doi.org/10.1080/ 13549839.2013.879289. 